\title{
Role of Micro Credit Program in Empowering Rural Women in Bangladesh: A Study on Grameen Bank Bangladesh Limited
}

\author{
Dhanonjoy Kumar'; Afjal Hossain²; \& Monto Chandra Gope ${ }^{3}$ \\ ${ }^{1}$ Assistant Professor, Department of Management, Islamic University, Kushtia, Bangladesh \\ ${ }^{2}$ Assistant Professor, Department of Marketing, Patuakhali Science and Technology University, Patuakhali, Bangladesh \\ ${ }^{3}$ Guest Faculty \& Former Senior Lecturer, Department of Business Administration, Metropolitan University, Sylhet, Bangladesh
}

\begin{abstract}
Bangladesh is one of the high density countries of the world. $40 \%$ of its population lives below the poverty level of which rural women are poorer. The rise of the Micro Credit Institution in the global context is identified as an important phenomenon which has implication for the development prospects of the poor. The paper was designed to identify the role of Grameen Bank (GB) and to analyze rural women's economic empowerment as the outcome of microcredit interventions. In this regard, an exploratory research has been made to focus on the activities and impacts after receiving micro-credit from GB. A sample size of 100 respondents has been interviewed through a structured questionnaire, in-depth interview and observation from Jhenaidah and Kushtia districts. The result shows that the women are more independent and can engage in decision making process after receiving and using micro credit.
\end{abstract}

Keywords: Grameen Bank, Micro Credit, Women, Empowerment, Bangladesh JEL Classification Code: M19

\section{INTRODUCTION}

$\mathrm{W}$ omen Women represent around $50 \%$ of the world population, and in many regions of the developing world, their contribution is immense in all the sectors of development. But still in today's world, women's position is not the same as their counterparts. Due to gender based discrimination and socially constructed sub-ordination women have inferior status everywhere in all the aspects of life i.e. political, economic, familiar or social. In Bangladesh like many other developing countries women's access to positions of influence and power is limited. Their occupational choices are narrower, and their earnings lower than those of men; and they must struggle to reconcile activities outside the home with their traditional roles. While men particularly among the poor also find themselves disenfranchised, it is a far more common experience among women. This experience is rooted in the failure to value women for anything but their reproductive role. The need for empowerment of women in Bangladesh arises from this harsh social scenario (Goswami, 1998: 45).

\section{LITERATURE REVIEW}

Literatures suggest that NGO interventions positively contribute to women empowerment (Ullah AKM, 2003: 21). NGOs central goal is empowering the powerless women folk or helping them to bloom their hidden potentialities which is power of thought, power of word, and power of organization with a view to helping them to participate in the socio economic development for their emancipation from less human condition to more human condition (Haider and Aktar, 1999: 57). The most extreme example of this discrimination can be seen in the third world countries. Bangladesh is a glaring example of this lowered status of women as well as of all sorts of gender based segregation. More than 60 million people of Bangladesh live below the poverty line among them $74 \%$ are women (Khan, Z. H 1998). In Bangladesh, the situations of rural women are more painful. Most of the rural women are deprived, to fulfill their basic needs. They become the victims of acid throwing, dowry, high mortality malnutrition, higher illiteracy etc. Now it is a dire need to let them raise their voice regarding human rights, decision making process, and moreover socio cultural and economic issues. One of the best ways of enabling women empowerment is access to credit, so that they can start to earn money. Bangladesh economy is characterized by unfavorable per capita land, low per capita income, glaring and accentuating income disparity, high level of unemployment, low productivity and persisting high levels of poverty and deprivation. Under the circumstances, micro credit has been promoted to help the poor especially the women to take self-employment on tiny or micro scales with a view to improving their living conditions. When income flow 
begins, then the right of food, shelter and everything also becomes a reality (Yunus, 1987). Rural poor women have little or no property of assets to offer as collateral which is required in formal banking system, micro credit has responded to the predicament by offering collateral free loans. Considering the role of creating self-employment opportunities, creating self-confidence, increasing awareness among women in Bangladesh, GB led the way, starting in the mid 1970s. Now there are hundreds of micro-credit providers of different operational sized throughout the country, mostly in rural areas but also some in urban areas. The large ones include GB, BRAC, ASA and PROSHEKA. Among them GB earned respectable status for Bangladesh in the international arena because of its poverty reduction strategies through which poor rural women are moving in the path of empowerment and development.

Presently in its wider dimension micro credit is known as microfinance and seen as a legitimate economic tool in the fight against poverty. The impact of giving credit to women has been a controversial issue. At one end of the spectrum, some argue that micro credit has positive impacts on gender equality, women's empowerment and households' well-being. On the other end of spectrum, microfinance is thought to bring negative impacts for women (Hulme, 2000). Concerning the positive impacts of microfinance on women, microfinance is claimed to help to reduce poverty by increasing consumption among microcredit program participants and their families, improving children's schooling, nutrition, increasing income and self-employment (Khandker, 1998, Pitt at al., 2006). Microfinance can reduce intimate partner violence in the household through participation of women in the credit programs and generate social capital for the participants (Julia et al., 2007; Pronyk et al., 2008) and access to credit can enhance women's economic independence, leading to women's self-esteem and status in the households and wider community (Goetz and Gufta, 1996; Kabeer, 2001). Moreover, women participating into micro credit programs improve their ability to exercise agency in the intra-household processes, to increase women's welfare resulting in decreasing male bias in welfare outcomes in the household; to increase the contraceptive use by women (Mahmud, 2003; Schuler \& Hashemi, 1994). Microfinance savings and MFIs also potentially help families in developing countries to cope with financial risks from main illnesses resulting from the cost of medical care and loss of income during illness (Gertler and Moretti, 2008).

\section{Objectives}

The objectives of this study are-

1. To identify the role of micro credit as a strategy for empowering women in Bangladesh.

Copyright @ 2013, Asian Business Consortium | ABR
2. To describe the ability of women as micro credit beneficiaries to take part in decision making process at the family level.

3. To examine their economic empowerment considering ability to increase their income level.

\section{Methodology of the Study}

Methodology plays an important role in any research. Appropriate methodology enables the researcher to collect valid and reliable information and to analyze the information properly to draw a clear-cut conclusion. The study used both qualitative and quantitative methods and 03 different data collection instruments. The research is a survey based exploratory research which was conducted using primary data. To collect primary data for the study several methods such as questionnaire, in-depth interview and observation as well as Focus Group Discussion (FGD) were used. Collected data was analyzed and interpreted through statistical techniques. Secondary data are used for the reanalysis of previously collected and analyzed data. Secondary sources were simply published books and articles by scholars. In this study, Jhenidah and Kushtia districts have been selected for some reasons. Several numbers of micro credit institutions especially selected GB is working and providing micro credit to landless women, divorced women, and widow women for many years. By collecting a list from regional GB Manager and officers' two branches were selected from GB. Among 5000 micro credit recipients approximately $2 \%$ households were the sample size of the study. The sample size (100) was selected randomly by simple random sampling method using random number.

\section{Key Concepts OF THE STUdY}

Micro-credit program plays an important role in socioeconomic development of rural poor especially for women. This study will help the selected organizations to know about the impact of micro credit on women empowerment. Women: A woman is an adult female human being, as contrasted to men, an adult male, and a girl, a female child. The term woman (irregular plural: women) is used to indicate biological sex distinctions, cultural gender role distinctions, or both (Wikimedia, 2005:1). Women constitute about half of the total population of the country. Apart from the household activities, they are contributing substantially to the national economy.

Empowerment: Empowerment means the transformation of structures of subordination, through radical changes in law, property rights, control over women's labor and bodies, and the institutions that reinforce and perpetuate male domination (Batliwala, 1993:5). But more specifically, the outcome of empowerment should manifest itself as a redistribution of power between individuals, genders, groups, classes, castes, races, ethnic groups or nations. Empowerment of women is now a global issue. Although this term is 
usually used for improving women's condition, in real sense it may be applied to any disadvantaged group of society for bringing them to the same level of advanced section. In simple sense, empowerment is a process which redistributes power from the powerful to the powerless. In the context of Bangladesh, empowerment of women means women should be given freedom of choice for fulfillment and self-development, as well as equal access to domestic and community resources, opportunities and power. In this study focus will be given on the strategic needs (decision making ability in the family, economic freedom like ability to make small and big purchases for her, children and family as well as her gendered position in the family and society).

Economic empowerment: Women's access to savings and credit gives them a greater economic role in decisionmaking through their decision about savings and credit. When women control decisions regarding credit and savings, they will optimize their own and the household's welfare. The investment in women's economic activities will improve employment opportunities for women and thus have a 'trickle down and out' effect. The financial sustainability and feminist empowerment paradigms emphasize women's own income generating activities. In the poverty alleviation paradigm, the emphasis is more on increasing incomes at the household level and the use of loans for consumption.

Social and political empowerment: A combination of women's increased economic activity and control over income resulting from access to micro-finance with improved women's skills, mobility, and access to knowledge and support networks. Status within the community is also enhanced. These changes are reinforced by group formation, leading to wider movements for social and political change. The financial self-sustainability paradigm and the poverty alleviation paradigm assume that social and political empowerment will occur without specific interventions to change gender relations at the household, community or macro-levels. By contrast, the feminist empowerment paradigm advocates explicit strategies for supporting women's ability to protect their individual and collective gender interests at the household, community and macro-levels (Mayoux, 2001).

Micro credit: The word credit' comes from Latin word' credo' meaning 'I believe or to trust'. Hence "credit" entails some one, the lender, to believe or trust some one, the borrower with funds to be used by the borrower for his /her purposes, to be repaid to the lender with interest at a later stage on agreed terms and conditions. Micro credit is the extension of very small loans (micro loans) to those in poverty designed to spur entrepreneurship. These individuals lack collateral, steady employment and a verifiable credit history and therefore cannot meet even the most minimal qualifications to gain access to traditional credit. Micro credit is a part of microfinance, which is the provision of a wider range of financial services to the very poor. Microcredit (mI-[*]Kro'kre-dit); noun; programmes extend small loans to very poor people for self-employment projects that generate income, allowing them to care for themselves and their families. Micro credit is a financial innovation that is generally considered to have originated with the GB in Bangladesh (Parvin, 1995). Micro-credit is based on a separate set of principles which are distinguished from general financing or credit. Micro-credit emphasizes building capacity of a micro-entrepreneur, employment generation, trust building and help to the micro entrepreneur on initiation and during difficult times. Micro credit is a tool for socio-economic development. United Nations former Secretary General Koffi Annan comments Micro credit is a critical anti-poverty tool-a wise investment in human capital. When the poorest especially women receive credit, they become economic actors with power, power to improve not only their own lives but in a widening circle of impact, the lives of their family, their communities and their nations. Micro credit loan cycles are usually shorter than traditional commercial loans-typically six months to a year with payments plus interest, due weekly. Shorter loan cycles and weekly payments help the borrowers may current and not become overwhelmed by large payments. Now in Bangladesh there are hundreds of micro credit providers of different operational sizes throughout the country, mostly in rural areas but also some in urban areas.

Grameen Bank: GB has reversed conventional banking practice by removing the need for collateral and created a banking system based on mutual trust, accountability, participation and creativity. GB provides credit to the poorest of the poor in rural Bangladesh without any collateral. At GB, credit is a cost effective weapon to fight poverty and it serves as a catalyst in the overall development of socio-economic conditions of the poor who have been kept outside the banking orbit on the ground that they are poor and hence not bankable. GB, the creation of Professor Dr. Yunus, began working in Jobra, Chittagong in 1976 as an action research project and became a full-fledged bank in 1983. It began up as a specialized financial micro credit providing institution offering services to rural poor (specially the women) without collateral. As the poor women is the most vulnerable group and have no access to formal banking system. As of October, 2011, it has 8.349 million borrowers, $97 \%$ of whom are women. With 2,565 branches, GB provides services in 81,379 villages, covering more than $97 \%$ of the total villages in Bangladesh.

Micro-enterprise Loans: Many borrowers are moving ahead in businesses faster than others for many favorable reasons, such as, proximity to the market, presence of experienced male members in the family, etc. GB provides larger loans, called micro enterprise loans, for these fast moving members. There is no restriction on the loan size. 
Asian Business Review, Volume 3, Number 2/2013 (Issue 6)

ISSN 2304-2613 (Print); ISSN 2305-8730 (Online)

Table 1: Top 25 Items in order of microenterprise loan amounts

\begin{tabular}{|c|c|c|c|}
\hline \multicolumn{4}{|c|}{ For Female Amount (Order Descending) } \\
\hline \multirow{2}{*}{ Serial } & \multirow{2}{*}{ Activity Name } & Female & Female \\
\hline & & No & Amount \\
\hline 1 & Grocery shop & 69,519 & $2,905,256,609$ \\
\hline 2 & Milch cow & 77,213 & $1,941,600,917$ \\
\hline 3 & Cow fattening & 85,165 & $1,653,469,667$ \\
\hline 4 & Rice/Paddy trading & 55,603 & $1,571,737,050$ \\
\hline 5 & Miscellaneous business & 59,606 & $1,282,521,942$ \\
\hline 6 & Paddy cultivation & 40,435 & $986,523,759$ \\
\hline 7 & Land lease & 26,000 & $723,757,874$ \\
\hline 8 & Vegetables trading & 30,723 & $707,683,291$ \\
\hline 9 & Bamboo works & 17,857 & $662,514,854$ \\
\hline 10 & Cloths trading & 17,800 & $615,207,116$ \\
\hline 11 & Stationery shop & 16,711 & $584,570,161$ \\
\hline 12 & Pisciculture & 21,784 & $535,886,563$ \\
\hline 13 & Fish trading & 16,298 & $461,406,362$ \\
\hline 14 & Plantation & 15,616 & $450,028,464$ \\
\hline 15 & Vegetables cultivation & 14,121 & $377,374,523$ \\
\hline 16 & Cane works & 9,198 & $335,213,688$ \\
\hline 17 & Rickshaw purchase & 11,353 & $287,138,995$ \\
\hline 18 & Poultry raising & 13,172 & $285,286,838$ \\
\hline 19 & Garments making & 5,764 & $281,336,474$ \\
\hline 20 & Cloths shop & 8,219 & $246,358,706$ \\
\hline 21 & Goat & 9,503 & $246,097,348$ \\
\hline 22 & Land cultivation & 10,572 & $244,679,717$ \\
\hline 23 & Farming & 9,911 & $242,891,372$ \\
\hline 24 & Rabi crop cultivation & 6,678 & $231,924,194$ \\
\hline 25 & Garden lease & 7,199 & $222,617,276$ \\
\hline
\end{tabular}

Source: Grameen Bank Annual report, 2010

Figure 1: Disbursement of Microenterprise Loans

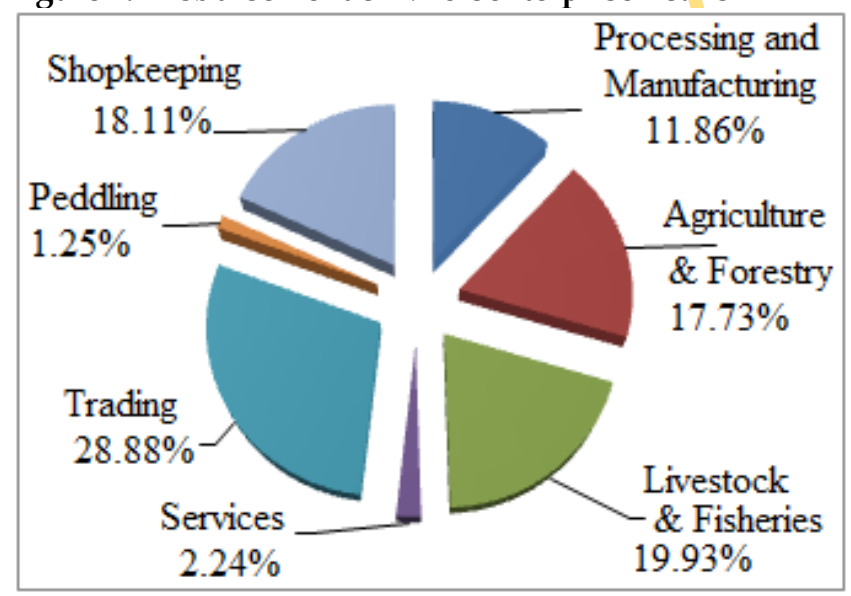

Source: Grameen Bank Annual report 2010.

\section{Measurement And Analysis of the StUdy}

Demographic Characteristics:

Demographic characteristics determine the characteristics of a person i.e. age, marital status, occupation, number of household members, sex, income level etc. Marital status of women is used to know the empowerment status and

socio-economic condition in this study. In the table 3 , it is shown that married respondents mostly contribute $(92 \%$ alone) in the socio-economic condition of the country with the help of micro credit. Education is another important variable for economic development. Class I-V is the large portion $(28 \%)$ of the total respondents who contribute for the economic development rather than others. It is evident that educated woman is much more conscious and aware about his economic condition than an illiterate woman $(42 \%$ can sign only).

Table 2: Demographic characteristics of the respondents

\begin{tabular}{|c|c|c|c|}
\hline & Frequency & $\begin{array}{l}\text { Nalid } \\
\%)\end{array}$ & $\begin{array}{l}\text { Cumula } \\
\text { five }(\%)\end{array}$ \\
\hline \multicolumn{4}{|l|}{ Marital Status Group } \\
\hline Married & 92 & 92 & 92 \\
\hline Single & 02 & 2 & 94 \\
\hline Divorced & 01 & 1 & 95 \\
\hline Widow & 04 & 4 & 99 \\
\hline Separated & 01 & 1 & 100 \\
\hline Total $=$ & 100 & 100 & \\
\hline \multicolumn{4}{|c|}{ A. Educational Status Group } \\
\hline Illiterate & 20 & 20 & 20 \\
\hline Can sign only & 22 & 22 & 42 \\
\hline Class I- V & 28 & 28 & 70 \\
\hline Class VI-X & 0 & 0 & 70 \\
\hline SSC & 27 & 27 & 97 \\
\hline Below HSC & 00 & 00 & 97 \\
\hline HSC & 03 & 03 & 100 \\
\hline Total $=$ & 100 & 100 & \\
\hline \multicolumn{4}{|c|}{ B. Occupational Status Group } \\
\hline Housewife & 87 & 87 & 87 \\
\hline Unemployed & 02 & 02 & 89 \\
\hline Self-employed & 05 & 05 & 94 \\
\hline Wage-labor & 01 & 01 & 95 \\
\hline Service holder & 04 & 04 & 99 \\
\hline Student & 01 & 01 & 100 \\
\hline Total $=$ & 100 & 100 & \\
\hline \multicolumn{4}{|l|}{ C. Income Source Group } \\
\hline Agriculture & 03 & 03 & 03 \\
\hline Maid Servant & 01 & 01 & 04 \\
\hline Ricks puller & 08 & 08 & 12 \\
\hline Resp. Service & 03 & 03 & 15 \\
\hline Husband Job & 25 & 25 & 40 \\
\hline Husband Business & 40 & 40 & 80 \\
\hline Sons Job & 03 & 03 & 83 \\
\hline Husband Massion & 04 & 04 & 87 \\
\hline Livestock Firm & 01 & 01 & 88 \\
\hline Own Business & 00 & 00 & 88 \\
\hline Father in laws Service & 01 & 01 & 89 \\
\hline Day Labour & 03 & 03 & 92 \\
\hline Electrician & 02 & 02 & 94 \\
\hline Van Puller & 06 & 06 & 100 \\
\hline Total $=$ & 100 & 100 & \\
\hline \multicolumn{4}{|c|}{ D. Monthly Income (Tk.) Group } \\
\hline $1,000-2,000$ & 06 & 06 & 06 \\
\hline $2,001-4,000$ & 30 & 30 & 36 \\
\hline $4,001-6,000$ & 20 & 20 & 56 \\
\hline
\end{tabular}




\begin{tabular}{|c|c|c|c|}
\hline $6,001-8,000$ & 04 & 04 & 60 \\
\hline $8,001-10,000$ & 06 & 06 & 66 \\
\hline $10,001-12,000$ & 0 & 0 & 66 \\
\hline $12,000+$ & 04 & 04 & 70 \\
\hline No comments & 30 & 30 & 100 \\
\hline Total $=$ & 100 & 100 & \\
\hline
\end{tabular}

Source: Field Survey, 2012

In the occupational perspective it is shown that housewife alone $87 \%$ is the contributors for his/ her development of the economic condition with the help of micro credit in Bangladesh. The income source of the female is largely on the husband business (40\%) because of their occupation is housewife. In case of monthly income it is shown that about $30 \%$ of the total respondents didn't say about their income level due to unwillingness. But it is also shown that $30 \%$ of the respondents income level is just within Tk. 2,001 $4,000 /=$ which is not satisfactory as today's cost of living.

That's why it is needed to engage with micro credit which is explained in the following tables (Table 3 and 4).

Table-03: Change of income source of the respondents after receiving credit

\begin{tabular}{|l|c|c|c|}
\hline $\begin{array}{c}\text { Sources } \\
\text { of Income }\end{array}$ & Frequency & Valid (\%) & $\begin{array}{c}\text { Cumula } \\
\text { tive (\%) }\end{array}$ \\
\hline Agriculture & 16 & 16 & 16 \\
Maid Servant & 01 & 01 & 17 \\
Ricks puller & 08 & 08 & 25 \\
Resp. Service & 03 & 03 & 28 \\
Husband Job & 10 & 10 & 38 \\
Husband Business & 25 & 25 & 63 \\
Sons Job & 05 & 05 & 68 \\
Husband Massion & 01 & 01 & 69 \\
Livestock Firm & 08 & 08 & 77 \\
Own Bisness & 14 & 14 & 91 \\
Father in laws & 01 & 01 & 92 \\
Service & & & \\
Day Labour & 01 & 03 & 95 \\
Electrician & 02 & 02 & 97 \\
Van Puller & 03 & 03 & 100 \\
\multicolumn{1}{r}{ Total = } & $\mathbf{1 0 0}$ & $\mathbf{1 0 0}$ & \\
\hline
\end{tabular}

Source: Field Survey, 2012

Sources of income play a vital role for the socio-economic development. Table 3 indicates that the highest number of income source is husband business is $25 \%$ decreased by $15 \%$ after receiving micro credit from GB. It is also shown that own business is increased by $14 \%$ because of taking this advantage. So, it is to say that GB members try to increase their individual income and engaged individual business.

Copyright (C) 2013, Asian Business Consortium | ABR
Table 4: Change of monthly income of the respondents after receiving micro credit.

\begin{tabular}{|l|c|c|c|}
\hline $\begin{array}{c}\text { Monthly } \\
\text { income (Tk.) }\end{array}$ & Frequency & Valid (\%) & Cumulative (\%) \\
\hline $1,000-2,000$ & 02 & 02 & 02 \\
$2,001-4,000$ & 12 & 12 & 14 \\
$4,001-6,000$ & 31 & 31 & 45 \\
$6,001-8,000$ & 11 & 11 & 56 \\
$8,001-10,000$ & 07 & 07 & 63 \\
$10,001-12,000$ & 02 & 02 & 65 \\
$12,000+$ & 10 & 10 & 75 \\
No comments & 25 & 25 & 100 \\
Total = & 100 & 100 & \\
\hline
\end{tabular}

Source: Field Survey, 2012

Table 4 denotes the changes of income level due to receive the micro credit from GB. It explains that the respondents didn't make any comment is $25 \%$ reduced by $5 \%$. It also explains that the highest level of income is Tk. 4,001 $6,000 /=$ of $31 \%$ whereas Tk. $2,001-4,000 /=$ was the highest income level before receiving micro credit. So, comparing before and after receiving credit from GB member's it can be said that income level is increased in each level of the followings (From Tk. 6,001 to Tk. 12,000 +).

\section{Role of Micro Credit Program}

Micro-credit play a vital role for women socio-economic development, as it affects on all aspects of their life. GB is involved in micro-credit operation by providing credit for various purposes to the women especially in empowering the poor rural women in Bangladesh. With the help of different sectors they are just focusing empowerment of the women in case of decision making process in the personal, family, social and even in national level, improvement of the life style and also in socio-economic development etc. From the study it is shown that most of the members (81\%) are satisfied about their (GB) credit facilities (credit sufficiency: Figure 2).

\section{Figure 2: Influence of Micro Credit Program}

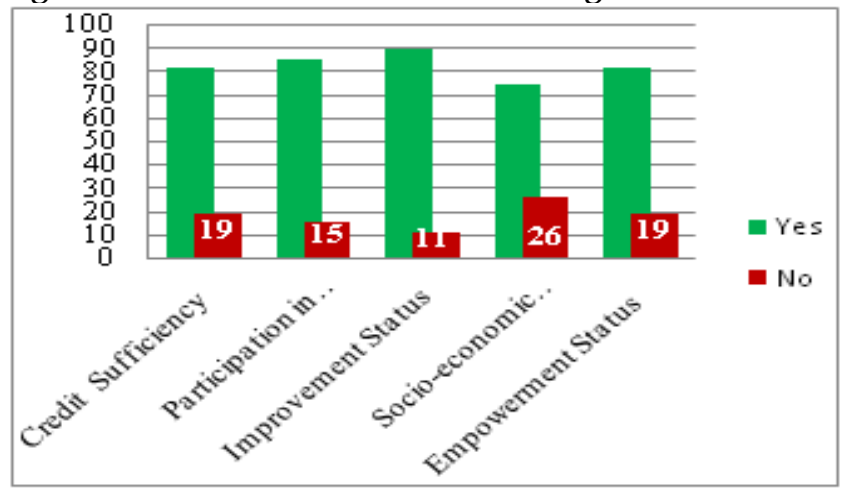

Source: Field Survey, 2012

Most of the members $(85 \%)$ were able to take part in decision making process after joining in the micro credit activities from GB, generating a good monthly income from the sources of income. Most of the members think that their 
life styles improvement start after receiving and using of micro credit. Most of the respondents (74\%) told that their socio-economic condition has improved after taking micro credit which has made them more confident and reliance. It has increased their sources of income, so women respondents were able to spent money to their own needs, purposes and for their family that has empowered (81\%) them in long term. So the researcher tried to assess the socio-economic condition of the respondents in the study for understanding their empowerment.

\section{FINDINGS OF THE STUDY}

The findings of this study are discussed here:

- It was found that most of the members are illiterate and their credit utilization ability is very weak.

- It was found that most of the members had small scale land. For this reason the members cannot use their capital to produce agricultural products.

- For the lack of proper knowledge and training the members cannot use their savings properly.

- It was seen that most of the respondents could take decision on using micro-credit. In focus group discussion and interview they revealed their husband gave importance of their opinion, so they can take a little decision on using micro credit.

- The woman entrepreneurs face various problems to marketing their products.

\section{RECOMMENDATIONS OF THE STUDY}

- The present study indicated that most of the women credit recipients were illiterate, so they had to depend on their husband to utilize their loan. That's why GB authority should concern to increase women literacy rate by which women can utilize loan with freedom that can ensure empowerment.

- The present study revealed that most of the credit recipients have successfully utilized their credit in non-agricultural purposes like poultry, livestock, and homestead gardening. So GB should need to increase the amount of credit from the beginning time for investment in non-agriculture purposes.

- GB authorities should need to take some initiatives for increasing women respondents' knowledge and efficiency though proper training courses.

- After micro credit disbursement, GB authorities should need to guidelines the members to use their credit amount individually not depends on other family member.

- It was found during focus group discussion that borrower entrepreneurs' women often face problems in the marketing operations. Though this is mainly due to the attitude of the society which can not be changed easily. GB can play a role through the provision of guidance to perform the marketing functions in organized groups especially in case of promoting and selling the products to the target people with fair price.

\section{ConClusion}

The main cause of poverty in Bangladesh is the lack of productive employment opportunities for the huge number of unemployed and under employed work force which is tremendously increasing and posing serious problems for the country. Nearly half of the populations in Bangladesh are women and most of them are living in the rural area of the country. They need to have engaged in income generating activities. So creating selfemployment for women in the rural areas can play a vital role in reducing the rural unemployment and acute poverty. It can be made through micro credit which will empower them too. The micro credit program of GB has benefited the poor women in more than one way. These programs enhanced their security giving them access to assets and rights and augmented their self-respect providing them choice and independence. Micro credit has enabled the poor women to undertake diversified economic activities which generate flow of stable income round the year and thus has strengthened survival strategy of the poor women. With micro credit, the poor households now own assets can use to meet contingencies without having to sacrifice their independence, security and peace of mind by getting into debt. Micro credit program has also empowered the beneficiaries by raising their social consciousness which is reflected among others in their increased participation in local government elections and social mobilization activities. Participation also has a beneficial effect on women's welfare since it increases their total employment time by reducing their other work responsibilities. Participation of women in micro credit program has also increased their mobility.

\section{Reference}

[1] Amin R. S. Becker and A. Bayes (1998), NGO- Promoted Micro Credit Programmes and Women's Empowerment in Rural Bangladesh: Quantitative and Qualitative Evidence. The Journal of Development Areas, Vol. 32, No. 02.

[2] Batliwala, Srilata (1993), Defining Women's Empowerment: A Conceptual Framework, www.genderatwork.org/updir/Batliwalaempowermentframework. html, retrieved on 10.05.2005.

[3] Gertler, P., Levine, D.I. and Moretti, E. (2008) “Do Microfinance Programs Help Families Insure Consumption against Illness?" Health Economics, John Wiley E Sons, Ltd., Vol. 18, No. 3, p. 257-273.

[4] Goetz, S., M., \& Sen Gupta, R. (1996) "Who Takes the Credit? Gender, Power, and Control Over Loan Use in Rural Credit Programs in Bangladesh", World Development, Vol. 24, No. 1, p. 45-63. 
[5] Goswami, Arun Kumar, (1998), Empowerment of Women in Bangladesh, Empowerment, vol. 5, Women for Women, Dhaka.

[6] Grameen Bank Annual Report, 2010.

[7] Haider, Rumel and Akhtar, Rasheda, (1999), the Role of NGO and Women's Perception of Empowennent: An Anthropological Study.

[8] Hulme, D., (2000) "Impact Assessment Methodologies for Microfinance: Theory, Experience and Better Practice", World Development Vol. 28, No.1, p.7-998.

[9] Islam and Sultana (2005), Role of NGOs in Empowering the Vulnerable Women: A Study on ACD, Asian Affairs, Vol. 27, No. 4, p. 24-40, October - December, 2005.

[10] Julia, C.K. Charlotte H. W., James R. H., Luceth X. N., Godfrey P.,, Linda A. M.,, Joanna B., John D.H. P. and Paul P. (2007) "Understanding the Impact of a Microfinance-Based Intervention on Women's Empowerment and the Reduction of Intimate Partner Violence in South Africa", American Journal of Public Health, October 2007, Vol. 97, No. 10.

[11] Kabeer, N., (2001) “Conflicts Over Credit: ReEvaluating the Empowerment Potential of Loans to Women in Rural Bangladesh" World Development Vol. 29 , No. 1 , p. 63-84.

[12] Khan and Ara (2006), Women, Participation and Empowerment in Local Government: Bangladesh Union Parishad Perspective. Asian Affairs, Vol. 29, No. 1, p. 73-00, January-March, 2006.

[13] Khan, Salma (1998), A Macro View of the Situation of Women in Bangladesh, the Fifty Percent, Women in Development and Policy in Bangladesh. The University Press Limited, Dhaka.

[14] Khandker, S. R., Samad, H. A. and Khan, Z. H (1998) "Income and Employment Effects of Micro-credit Programs: Village Level Evidence from Bangladesh", The Journal of Development Studies, Vol. 35, No. 2, p. 96-124.
[15] Mahmud, S. (2003) "Actually how Empowering is Microcredit?" Development and Change Vol. 34, No. 4, p. 577-605.

[16] Mayoux, Linda (2001), "Micro-Finance and The Empowerment of Women" A Review of the Key Issues" (Online) Available at $\mathrm{J}: \backslash$ ilo_data \public \english \employment $\backslash$ finance $\backslash$ do wnload \wp23.wd.

[17] Micro Credit Summit (1997), “Declaration and Plan of Action". (Online) Available at http// www.microcreditsummit.org/ declaration.html.

[18] Parvin. S (1995), "Empowering Women: Problem and Potentiality." Paper prepared for presentation at the $11^{\text {th }}$ Biennial Conference of the Bangladesh Economic Association, Dhaka, July 29-31.

[19] Pitt, M. M., Khandker, S. R. and Cartwright, J. (2006) "Empowering Women with Microfinance: Evidence from Bangladesh", Economic Development and Cultural Change, p. 791- 831.

[20] Pronyk, P.M., Harpham, T., Busza, J., Phetla, G., Morison L.A., Hargreaves J.R., Kim J.C., Watts, C.H. and Porter, J.D. (2008) "Can social capital be intentionally generated? A randomized trial from rural South Africa" Social Science \& Medicine 67 (2008) 1559-1570.

[21] Schuler, S. R. and Hashemi, S. M. (1994) "Credit Programs, Women's Empowerment, and Contraceptive use in Rural Bangladesh", Studies in Family Planning, Vol. 25, No. 2 (Mar. - Apr., 1994), p. 65-76.

[22] Ullah, AKM Ahsan, (2003), Empowerment of Women in Bangladesh: Do NGO Interventions Matter? Empowerment, vol. 10, Women for Women, Dhaka.

[23] Wikimedia (2005). 22nd July .http://en.wikipedia.org/wiki/women, Retrieved on 24.07.2005.

[24] Yunus Muhammad (2006), Microcredit: Banking With the Poor without Collateral. 